\title{
Developing Democratic Engagement in School: can becoming co-operative help?
}

DOI:

10.15730/forum.2016.58.3.363

\section{Document Version}

Final published version

Link to publication record in Manchester Research Explorer

\section{Citation for published version (APA):}

Ralls, D. (2016). Developing Democratic Engagement in School: can becoming co-operative help? FORUM for promoting 3-19 comprehensive education, 58(3), 365-373. https://doi.org/10.15730/forum.2016.58.3.363

\section{Published in:}

FORUM for promoting 3-19 comprehensive education

\section{Citing this paper}

Please note that where the full-text provided on Manchester Research Explorer is the Author Accepted Manuscript or Proof version this may differ from the final Published version. If citing, it is advised that you check and use the publisher's definitive version.

\section{General rights}

Copyright and moral rights for the publications made accessible in the Research Explorer are retained by the authors and/or other copyright owners and it is a condition of accessing publications that users recognise and abide by the legal requirements associated with these rights.

\section{Takedown policy}

If you believe that this document breaches copyright please refer to the University of Manchester's Takedown Procedures [http://man.ac.uk/04Y6Bo] or contact uml.scholarlycommunications@manchester.ac.uk providing relevant details, so we can investigate your claim.

\section{OPEN ACCESS}




\title{
Developing Democratic Engagement in School: can becoming co-operative help?
}

\author{
DEBORAH RALLS
}

\begin{abstract}
One hundred years have passed since John Dewey's seminal Democracy and Education (1916), yet academics and practitioners continue to search for ways in which democratic relationships in education can be enacted. This article uses a case study of an English Co-operative school to explore how far becoming co-operative can support a shift in the type of engaged relationships that schools have with stakeholders (students, parents, community) towards Dewey's participatory democracy in education. Can Cooperative schools offer the potential to envision an alternative to current English education policy discourse by engaging students and families as members of a collective democracy rather than as individual consumers? The author shows where forms and understandings of engagement offer potential for democratic relationships through processes of democratic governance and collective responsibility. The article also explores the tensions that emerge between Co-operative school practices and external policy constraints, and the challenges of becoming co-operative.
\end{abstract}

\section{Introduction}

This article presents findings from a case study on stakeholder (student, parent and community) engagement in a new type of state school in England, a Cooperative school. This research focused on a critical case study of a school actively seeking to establish forms of stakeholder engagement that would support the development of more democratic relationships. There is a gap in research and policy in terms of knowledge of the processes involved in developing democratic engagement in schools, particularly with regard to the experiences of stakeholders, as well as professionals. Yet such knowledge is crucial if we are to move away from understandings of engagement based on professionally driven interventions rather than collective endeavour. This article addresses this gap and highlights the experiences of a wider spectrum of those 
involved by conducting an exploration of what engagement looks like in practice.

In addition to Dewey's notion of participatory democracy in education, this article draws upon the concept of a relational approach to engagement as espoused by Warren et al (2009). A relational approach to engagement is defined as a school and its stakeholders getting things done collectively, starting from the point of their 'shared interest in advancing the education and wellbeing of children' (Warren et al, 2009, p. 2213), an approach that could help support more democratic forms of engagement in schools.

\section{The Emergence of Co-operative Schools}

The rapid growth of Co-operative schools in England has exceeded expectation, from the appearance of the first Co-operative school in 2008 to the establishment of over 800 schools in 2016. The development is such that it has been described as a quiet revolution (Thorpe, 2013). The Co-operative schools model has been born out of a capitalist command economy (Monbiot, 2013) that has resulted in English education policy reforms which have led to the marketisation of state education. This has resulted in a contemporary English educational landscape that houses an unprecedented assortment of alternatives marketed through the rhetoric of freedom and choice.

Against this background, Co-operative schools have emerged, schools that present the possibility of doing things differently. Co-operative schools are state schools with an ethos based on the globally shared co-operative values of selfhelp, self-responsibility, democracy, equality and equity, and solidarity. In becoming a Co-operative school, schools agree to apply these values throughout the school, in their governance, pedagogy, curriculum and ethos (Woodin, 2015). Parents and carers, staff, students and the local community have direct engagement in the governance of the school through membership, making each Co-operative school a community-based mutual organisation. Woodin (2015, p. 5) explains how Co-operative schools emerged as an 'unintended consequence' of the marketisation of the English education system, providing some hope that education can be refashioned 'along more democratic and community based lines' (p. 5). This has led to Co-operative schools being seen as an attractive alternative to other academy schools.

\section{Methodology: the research site and data}

Blakemore School [pseudonym] provides the setting for the case study. The school took the decision to convert from a local authority state school to become a Co-operative academy in January 2013. Blakemore School is a larger than average co-educational comprehensive school in a large conurbation in the north of England. Students attending the school come from a wide range of socio-economic backgrounds from around the conurbation. The proportion of students known to be eligible for free school meals is well above the national 
average. Just over half the students have minority ethnic heritage, and a significant proportion of these speak English as an additional language. The proportion of students with learning difficulties and/or disabilities, including those with a statement of special educational needs, is slightly above the national average.

Data collection took place in negotiation with the school over a 10-month period from September 2014 to July 2015. The main aim was to understand how development of and commitment to stakeholder engagement was happening in practice. Approaches to and perceptions of engagement were explored from the perspectives of both the school as an institution and its stakeholders: the students, their parents and the wider community. Drawing on Warren's (2009) concept of relational engagement, staff, parents, students and community members were asked about their engagement experiences, through three separate semi-structured interviews (staff) and a total of six focus groups (two each for parents, students and community members). The school identified staff participants with specific roles and responsibilities linked to engagement. Students, parents and community members were selected based on their involvement in 'best case' engagement activities, where the school felt it was trying to move towards doing with rather than doing to stakeholders. Staff suggestions of best case activities of engagement as doing with were then used to observe engagement in action so as to compare what was observed with the accounts given in the staff interview data and stakeholder focus groups.

The following section discusses two key findings from the research; the first surfaces the potential that the co-operative model can offer for democratic forms of engagement in schools, whilst the second finding illuminates the challenges faced by a Co-operative school seeking to measure up to external standards.

\section{Findings}

\section{Democratic Engagement and Power Shifts}

The study found that Co-operative school governance offered the potential for more democratic, relational forms of engagement with stakeholders. Student engagement was most positively affected by the conversion to a Co-operative school, with the relaunch of a democratically elected Student Council resulting in a far broader range of engagement of young people from different socioeconomic and ethnic backgrounds in increased levels of school decision making. The form of engagement that staff sought with students in this particular context had been specifically informed by one key factor: Blakemore School's conversion to a Co-operative school. The relaunch of a co-operative Student Council had also caused school leaders to question their previous perceptions of student engagement as a result of the shift in the power dynamic that had occurred since the relaunch of the Student Council, and this resulted in a more relational approach to student engagement than had previously been the case. It 
was evident from the data that more democratic modes of engagement had taken place following the school's conversion to a Co-operative school:

It [the Student Council] wasn't very active in the period before September. They met periodically but there wasn't a structured set of meetings. The membership of the Council was kind of historical really and it rolled over year on year ... We wanted to make it democratic and you to be voted on ... It was very popular. In Year 7 and Year 8 we had 15 people standing in some form groups ... It did tap into a new group of people ... The democratic purpose and that value that the students themselves personally feel about it is much higher I think. It's much more valued as a role. (Sally, School Business Manager)

The relaunch of the Student Council following Blakemore's conversion to a Cooperative school had evidenced positive developments in three core elements of a relational approach to engagement as defined by Warren et al (2009, p. 2210):

(i) relationship building among and between stakeholders (in particular, student-student and students-staff);

(ii) a focus on the leadership development of students;

(iii) efforts to bridge the gap in culture and power between students and educators.

These findings demonstrated how the implementation of a co-operative governance structure for students had led to changes in forms and understandings of student engagement over time. It was evident that a greater number of young people now had a forum to discuss a wider variety of topics than had previously been possible. Students were able to put their views forward to a different audience, including those who traditionally held the greatest positions of power in a school, the Senior Leadership Team and the school governors:

I challenged myself in becoming a Student Council Form Rep - just to see if I could. I got to become a Form Rep ... The first year council meeting they asked who wanted to be on the Whole School Council. - I thought: 'I have got this far, why not further?' I made a video with a speech. It was played in the year assembly - very embarrassing. I built up a good relationship with people from the Whole Council, which helped me become Chair. I now attend governors' meetings with Danielle (Vice Chair) - it's a big responsibility but also lots of fun - I really enjoy it. (Lily, Year 9: Chair of Whole School Council)

The relaunch of a cooperative School Council had also caused school leaders to question their previous perceptions of student engagement as a result of the shift in the power dynamic that had occurred since the relaunch of the Student 
Council, with an increasing awareness of the importance of two-way communication between students and staff:

Previously I've always focused on students' engagement in the lessons through the class teacher ... I suppose, thinking about what you've said, I've always thought about it as students as a done to; I've always kind of done it through the teacher.

So this role [responsibility for the Student Council] is very different. It's working with students, as in working directly with students, which I'm really enjoying. It's opened my eyes actually to some of the things that they can do ... Since September, what it's really opened my eyes to is students do care, students do want to participate and that they are independent and they do want to have a say and I think that has really opened my eyes since September. (Nicola, Deputy Head Teacher)

The organisational and operational structure of the co-operative School Council had thus initiated a shift away from traditional top-down communication from teacher to student (Warren et al, 2009) towards a two-way, more dialogic encounter (Fielding, 2001):

I think it [the new co-operative structure] opens up engaging the students in decisions much, much more ... It's given me that push, that 'right, OK, we can't be making unilateral decisions, we need to pull the young people in'. (Michael, Director of Engagement)

For the students, at least, this study shows that conversion to a Co-operative school, and the relaunch of the School Council that occurred as a result, was a major factor in influencing movements towards democratic forms of engagement. The emphasis on co-operative values resulted in students and staff seeing the School Council, and its purpose, as part of a democratic process where students were seen as partners and decision makers to work with, not just do to. Efforts were clearly being made to view school issues and developments as a shared endeavour to be undertaken by staff and students in collaboration (Thomas, 2012). These findings invite the need for further research into the connection between co-operative governance structures in schools and the more relational forms and understandings that can develop as a result of the co-operative impetus to do things democratically. However, future research would also have to consider whether all stakeholders are pulled in and engaged in decisions in the same way. This research shows that the same co-operative structures were not yet in place for parents and community members to engage with schools in order to experience solidarity and co-operation in practice (Freire, in Rossatto, 2005), resulting in less relational patterns of engagement for parents and community members; the most relational shifts had occurred in the student engagement context. 


\section{Insiders or Outsiders? Power Struggles}

Stakeholder responses showed that students and staff were viewed as 'the school' and demonstrated greater accord in their understandings of engagement, whereas with parents and community members, viewed as outsiders, tensions emerged as stakeholders and staff feel that one was attempting to impose their views (or do to) the other. As discussed in the previous section, it was found that the co-operative school governance structure gave more potential for democratic, relational engagement. However, analysis showed that, in spite of the co-operative governance structure, students and staff were afforded more opportunities for democratic engagement, whereas with parents and community members, often viewed as outsiders, tensions could emerge as stakeholders and staff felt that some were attempting to impose their views (or do to) the other.

The insights from the data showed that a sense of belonging to the school, of being part of Blakemore School's community, was not shared across the stakeholder groups. Feelings of belonging and of who was viewed as an insider or outsider impacted on the forms and understandings of engagement that developed and the purposes of these activities and relationships. Why was this so?

In considering the potential for engagement, this study points to the need to consider relationships beyond those that can be developed among and between the stakeholder groups. I argue that it is necessary to look further than these relationships to explore how schools can overcome this sense of outsideness (Relph, 1976) that makes it difficult for schools to develop more relational approaches in practice. This research suggests that models of parent engagement promoted by government policy have an impact on understandings and, therefore, purposes and forms of engagement in a Co-operative school setting and the potential for democratic engagement. The repositioning of parents as consumers, where parent voice is increasingly being reconstructed as the right to 'raise complaints', 'challenge the school' and 'vote with their feet' (Morgan, 2106) fuels the tendency for staff to see parents as outsiders, as potential foes rather than allies, and as such it is understandable that at times Blakemore School appeared to be adopting a defensive rather than outwardlooking approach to parent engagement (Massey, 1991). Policy trends in education have presented schools with challenges in parent and community engagement, due to the fear of academic results faltering:

At the minute there's constant hurdles popping up that draw your attention and your focus. But maybe, if you invest time and effort in your community and outside of the school, maybe there'll be the trust in you to weather any storms. We can't go on going like this forever, it's impossible, there's going to be a dip. This Year 11 are [a lower ability year] - we're scared. What I suppose we're worried about is you're selling a story, a lifestyle, a future for young people and at the minute it looks like that (gestures an upward sweep) but it 
could look like that (downward sweep). (Helen, Deputy Head

Teacher - Curriculum)

Helen's comments suggest that the burden of bureaucracy and constant changes in education policy (Coffield et al, 2007), together with the 'ongoing pressure for performativity' (Jephcote \& Salisbury, 2009, p. 966), can destabilise a school's efforts to act more relationally and affect forms of participatory democratic engagement. Rather than investing time and effort in your community and outside of the school' (Helen), schools are instead left 'bowling alone' (Eaude, 2009). In this way the marketisation of education in England may act to restrict rather than facilitate possibilities for more relational approaches to engagement. Policy positions parents and community members as school outsiders, leading to power struggles, as one set of stakeholders seeks to do to the other rather than work with one another.

\section{Conclusion: repositioning schools}

This article demonstrates how becoming co-operative can help in developing more democratic engagement between schools and their stakeholders. However, it shows how positions matter (Holland et al, 1998) and how policy impacts on positionality, with democratic relationships more evident when stakeholders are seen as part of the school (staff and students) rather than positioned outside the school (parents and community members). If democratic engagement is to become a widespread reality in schools, then it is vital for policy makers to change their understanding of schools and their purpose, to see beyond the conceptualisation of school as a marketable commodity that advocates an individualistic view of student success (Thomas, 2012). There is a need for new policy thinking that rejects the notion of students, parents and community members as choosers and consumers and instead repositions stakeholders as a collective public in education. This would involve a school and its stakeholders getting things done collectively, starting from the point of their 'shared interest in advancing the education and well-being of children' (Warren et al, 2009, p. 2213). Only then can Co-operative schools truly flourish.

\section{References}

Coffield, F., Edward, S., Finlay, I., et al (2007) How Policy Impacts on Practice and how Practice Does Not Impact on Policy, British Educational Research Journal, 33(5), 723-741. http://dx.doi.org/10.1080/01411920701582363

Dewey, J. (1916) Democracy and Education: an introduction to the philosophy of education. New York: The Free Press (first published by Collier-Macmillan, 1966).

Eaude, T. (2009) Bowling Alone? What Can Schools Do to Promote Cobesive Communities? London: National Education Trust.

Fielding, M. (2001) Students as Radical Agents of Change, Journal of Educational Change, 2(2), 123-141. http://dx.doi.org/10.1023/A:1017949213447 
Holland, D., Lachicotte, W. Jr, Skinner, D. \& Cain, C. (1998) Identity and Agency in Cultural Worlds. Cambridge, MA: Harvard University Press.

Jephcote, M. \& Salisbury, J. (2009) Further Education Teachers' Account of their Professional Identities, Teacher and Teacher Education, 25(7), 966-972. http://dx.doi.org/10.1016/j.tate.2009.05.010

Massey, D. (1991) A Global Sense of Place, Marxism Today, June, pp. 24-29.

Monbiot, G. (2013) A Capitalist Command Economy, The Guardian, 4 March. https://www.theguardian.com/commentisfree/2013/mar/04/educationcapitalist-command-economy (accessed 25 July 2016).

Morgan, N. (2016) Educational Excellence Everywhere. King's College School of Mathematics, London. 17 March. https://www.gov.uk/government/speeches/nicky-morgan-educationalexcellence-everywhere

Relph, E. (1976) Place and Placelessness. London: Pion.

Rossatto, C.A. (2005) Engaging Paulo Freire's Pedagogy of Possibility: from blind to transformative optimism. Lanham, MD: Rowman \& Littlefield.

Thomas L. (2012) Retbinking the Importance of Teaching: curriculum and collaboration in an era of localism. London: Royal Society of Arts.

https://www.thersa.org/globalassets/pdfs/blogs/rsa-re-thinking-the-importanceof-teaching.pdf (accessed 25 July 2016).

Thorpe, J. (2013) Co-operative Schools: a quiet revolution, Journal of Co-operative Studies, 46(2), 6-9.

Warren, M.R., Hong, S., Rubin, C.L. \& Uy, P.S. (2009) Beyond the Bake Sale: a community-based relational approach to parent engagement in schools, Teachers College Record, 111(9), 2209-2254.

Woodin, T. (2015) Co-operation, Learning and Co-operative Values: contemporary issues in education. Abingdon: Routledge.

DEBBIE RALLS is currently finishing her PhD studentship at the University of Manchester. Her thesis explores forms and understandings of engagement in a co-operative school setting, focusing on the potential to develop more equitable relationships between schools and their students, parents and community members. Prior to commencing her $\mathrm{PhD}$ Debbie worked as a teacher and teacher educator in both further and higher education, teaching on and developing literacy, ESOL (English for Speakers of Other Languages) and Postgraduate Certificate in Education programmes and managing an alternative education provision for 13-19-year-olds.

Correspondence: deborah.ralls@postgrad.manchester.ac.uk 